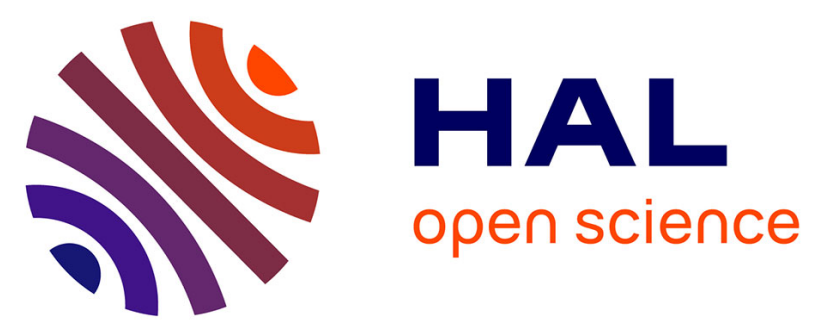

\title{
Hydrogen production from hydrocarbons over Rh supported on Ce-based oxides for automotive applications
}

\author{
S. Rijo Gomes, N. Bion, Daniel Duprez, F. Epron
}

\section{- To cite this version:}

S. Rijo Gomes, N. Bion, Daniel Duprez, F. Epron. Hydrogen production from hydrocarbons over Rh supported on Ce-based oxides for automotive applications. Applied Catalysis B: Environmental, 2016, 197 (4), pp.138 - 145. 10.1016/j.apcatb.2016.01.022 . hal-01658250

\author{
HAL Id: hal-01658250 \\ https://hal.science/hal-01658250
}

Submitted on 20 Aug 2021

HAL is a multi-disciplinary open access archive for the deposit and dissemination of scientific research documents, whether they are published or not. The documents may come from teaching and research institutions in France or abroad, or from public or private research centers.
L'archive ouverte pluridisciplinaire HAL, est destinée au dépôt et à la diffusion de documents scientifiques de niveau recherche, publiés ou non, émanant des établissements d'enseignement et de recherche français ou étrangers, des laboratoires publics ou privés. 


\section{Hydrogen production from hydrocarbons over Rh supported on Ce-based}

\section{oxides for automotive applications}

S. Rijo Gomes, Nicolas Bion, D. Duprez and F. Epron*

Université de Poitiers, CNRS UMR 7285, Institut de Chimie des Milieux et Matériaux de Poitiers (IC2MP), 4 rue Michel Brunet, TSA 51106, 86073 Poitiers Cedex 9, France

*Corresponding author. Tel.: +33 5494548 32; fax: +33 549453741

E-mail address: florence.epron@ univ-poitiers.fr 


\begin{abstract}
On-board hydrogen production by reforming of fuel in the exhaust gas recirculation loop allows increasing the engine yield, thus decreasing the fuel consumption, and the formation of pollutants such as NOx. Various catalysts based on Rh supported on cerium-based oxides with alumina were prepared and characterized. Their catalytic performances were evaluated in the reforming of isooctane, chosen as model molecule, in the presence of a gas mixture of composition representative of the exhaust gas, i.e. $\mathrm{H}_{2} \mathrm{O}, \mathrm{CO}_{2}, \mathrm{O}_{2}$ and $\mathrm{N}_{2}$. It was shown that the best performances in terms of hydrogen yield were obtained with the supports containing both ceria, in high amounts, and alumina, due to the high thermal stability of the support, the high metal dispersion and the limited sintering.
\end{abstract}

Key-words: Hydrogen production, catalytic fuel reforming, ceria-based supports, rhodium 


\section{Introduction}

In vehicles Exhaust Gas Recirculation (EGR) technique was initially developed for decreasing the temperature in the combustion chamber to limit NOx production in Diesel engines. It is now commonly used for gasoline engines with direct injection spark ignition working in lean burn conditions, for which the conventional three way catalysts cannot work efficiently. EGR also reduces throttling losses in gasoline engine, and consequently fuel consumption [1]. On-board Hydrogen production by reacting fuel with exhaust gas [2-7] in the presence of a catalyst process may enhance the efficiency of EGR systems. In this process, schematized in Fig. 1, hydrogen is virtually produced by reaction of hydrocarbons with the main components of the exhaust gas, $\mathrm{CO}_{2}$ and $\mathrm{H}_{2} \mathrm{O}$, by dry and steam reforming, respectively. These two reactions being endothermic, this allows to recover energy from the exhaust gas [7]. Other reactions, such as total, partial oxidation or water-gas-shift reactions may also occur but their contribution is minority in the whole process [7]. Small amount gasoline may be added in the system to increase the amount of hydrogen produced. The combustion in the engine with a gas enriched in $\mathrm{H}_{2}$, by this process named Reforming of Exhaust Gas Recirculation (REGR), increases the ratio $\mathrm{H} / \mathrm{C}$ of the fuel, decreasing the production of $\mathrm{CO}$ and the fuel consumption by an increase of combustion efficiency $[2,7,8]$.

Rhodium-based mono or bimetallic catalysts have proven their efficiency for producing hydrogen in the REGR conditions [9-11], i.e. in the presence of a fuel, water, $\mathrm{CO}_{2}, \mathrm{O}_{2}$ and $\mathrm{N}_{2}$. In the REGR conditions, mainly steam and dry fuel reforming may occur. We have shown [12] that $\mathrm{Rh}(1 \mathrm{wt} \%)$ supported on zirconia doped with $26.2 \mathrm{wt} \%$ of a mixture of $\mathrm{La}_{2} \mathrm{O}_{3}, \mathrm{Nd}_{2} \mathrm{O}_{3}$ and $\mathrm{Y}_{2} \mathrm{O}_{3}$ (ZLNY support) exhibited high activity for REGR gasoline process application, using isooctane $\left(\mathrm{C}_{8} \mathrm{H}_{18}\right)$ as a model molecule. Despite a partial $\mathrm{C}_{8} \mathrm{H}_{18}$ conversion, high $\mathrm{H}_{2}$ yields were obtained, with $\mathrm{CH}_{4}$ yields lower than those predicted at the thermodynamic equilibrium. The 
study (i) on the effect of water, $\mathrm{CO}_{2}$ and REGR condition, i.e. the study of the steam reforming, dry reforming and REGR reactions separately, in various conditions of temperature and contact time and (ii) on the conversion of methane and its production by $\mathrm{CO}$ or $\mathrm{CO}_{2}$ methanation, or by $\mathrm{C}_{8} \mathrm{H}_{18}$ hydrogenolysis or decomposition, enabled us to propose a reaction scheme in 3 successive steps for isooctane conversion in REGR conditions, i.e. the reforming of isooctane in the presence of water, carbon dioxide and oxygen [13], yielding $\mathrm{H}_{2}$ and $\mathrm{CO}_{2}, \mathrm{CO}$ and $\mathrm{CH}_{4}$ : - Step 1, corresponding to reforming reactions i.e. steam reforming (eq. (1) and dry reforming (eq.(2)) yielding $\mathrm{H}_{2}$ and mainly $\mathrm{CO}_{2}$, dry reforming reaction being negligible :

$$
\begin{aligned}
& \mathrm{C}_{8} \mathrm{H}_{18}+16 \mathrm{H}_{2} \mathrm{O} \rightarrow 8 \mathrm{CO}_{2}+25 \mathrm{H}_{2} \\
& \mathrm{C}_{8} \mathrm{H}_{18}+8 \mathrm{CO}_{2} \rightarrow 16 \mathrm{CO}+9 \mathrm{H}_{2}
\end{aligned}
$$

Step 2, corresponding to the reverse water gas shift (RWGS) reaction, yielding CO:

$$
\mathrm{CO}_{2}+\mathrm{H}_{2} \leftrightarrow \mathrm{CO}+\mathrm{H}_{2} \mathrm{O}
$$

Step 3, corresponding to methanation reactions, especially with $\mathrm{CO}$, yielding $\mathrm{CH}_{4}$ : $2 \mathrm{CO}+2 \mathrm{H}_{2} \leftrightarrow \mathrm{CH}_{4}+\mathrm{CO}_{2}$

The partial and total oxidation reactions were negligible, except for low isooctane conversions, due to the small amount of $\mathrm{O}_{2}$ in the gas phase compared to those of $\mathrm{H}_{2} \mathrm{O}$ and $\mathrm{CO}_{2}$ in REGR reaction. A slight deactivation was observed, which was attributed to either the metal sintering or a poisoning of the $\mathrm{Rh} /$ support interface.

The stability of reforming catalysts depends strongly on the nature of the support and on the metal-support interactions. Ceria-based supports present interesting properties for reforming reactions since (i) ceria favors strong metal-support interactions, thus limiting metal sintering [14] and (ii) is able to release oxygen and reduce its valence from $\mathrm{Ce}^{4+}$ to $\mathrm{Ce}^{3+}$ in oxygen-poor environments, and re-oxidize in oxygen-rich environments, which helps preventing deactivation by coke deposition [15]. 
In the present study, production of hydrogen from isooctane will be investigated in the presence of rhodium catalysts supported on cerium-based oxides with alumina in REGR conditions, as the previous ones $[12,13]$. Alumina was added to improve the stability of the ceria based support. The supports will be $\mathrm{CeO}_{2}-\mathrm{Al}_{2} \mathrm{O}_{3}$, which has demonstrated high ceria reducibility $[16,17]$ and $\mathrm{CeO}_{2}-\mathrm{ZrO}_{2}(50: 50) / \mathrm{Al}_{2} \mathrm{O}_{3}, \mathrm{CeO}_{2}-\mathrm{ZrO}_{2}$ (50:50) presenting high oxygen mobility [18] and favoring high performances for REGR reaction [19].

2. Experimental conditions

\subsection{Catalysts}

Five supports were used: $\gamma \mathrm{Al}_{2} \mathrm{O}_{3}, \mathrm{CeO}_{2}, \mathrm{Al}_{2} \mathrm{O}_{3}(80 \%)-\mathrm{CeO}_{2}(20 \%), \mathrm{Al}_{2} \mathrm{O}_{3}(20 \%)-\mathrm{CeO}_{2}(80 \%)$, $\mathrm{Ce}_{0.5} \mathrm{Zr}_{0.5} \mathrm{O}_{2} / \mathrm{Al}_{2} \mathrm{O}_{3}(10 \%)$. In the following they will be named: $\mathrm{Al}_{2} \mathrm{O}_{3}, \mathrm{CeO}_{2}, \mathrm{Al}(80) \mathrm{Ce}(20)$, $\mathrm{Al}(20) \mathrm{Ce}(80)$, these four supports corresponding to the $\mathrm{Al}(\mathrm{Cex})$ series, and $\mathrm{CeZrAl}$, respectively.

$\mathrm{Al}_{2} \mathrm{O}_{3}$ was provided by Axens and $\mathrm{CeO}_{2}$ by Solvay (Rare-earth systems). $\mathrm{Al}(80) \mathrm{Ce}(20)$ was prepared by impregnation of $\mathrm{Ce}\left(\mathrm{NO}_{3}\right)_{3} \cdot 6 \mathrm{H}_{2} \mathrm{O}$ on the commercial $\mathrm{Al}_{2} \mathrm{O}_{3}$ support in excess of water. $\mathrm{Al}(20) \mathrm{Ce}(80)$ and $\mathrm{CeZrAl}$ were prepared by a sol-gel method adapted from [20]. After evaporation of water, supports were dried and then calcined at $800^{\circ} \mathrm{C}$ in a muffle furnace for $5 h$.

Rhodium (1 wt\% Rh) was impregnated on the support by wet impregnation technique using rhodium(III) chloride (Alfa Aesar). After evaporation of the solvent, the as-made sample was dried, and then calcined at $650{ }^{\circ} \mathrm{C}$, under air flow $\left(60 \mathrm{~cm}^{3} \mathrm{~min}^{-1}\right)$ for $4 \mathrm{~h}$ (temperature ramp: 2 $\left.{ }^{\circ} \mathrm{C} \min ^{-1}\right)$.

\subsection{Characterization}

The specific surface area of the catalysts was estimated by the BET (Brunauer-Emmett-Teller) model using nitrogen adsorption at $-196{ }^{\circ} \mathrm{C}$ in a Tristar 3000 Micromeritics apparatus. The pore size distribution was calculated using BJH (Barret-Joyner-Halenda) model. 
The metal content was determined by elemental analysis using inductively coupled plasma atomic emission spectroscopy (ICP-AES) technique in a Perkin Elmer Optima 2000 DV apparatus.

Rh accessibility was measured by $\mathrm{H}_{2}$ chemisorption. Typically $120 \mathrm{mg}$ of sample were reduced in flowing hydrogen at $400{ }^{\circ} \mathrm{C}\left(1 \mathrm{~h}\right.$, heating rate $\left.10{ }^{\circ} \mathrm{C} / \mathrm{min}\right)$, flushed under $\operatorname{Ar}(3 \mathrm{~h})$, and then cooled down to room temperature under flowing Ar. The $\mathrm{H}_{2}$ uptake measurements were performed at $-86{ }^{\circ} \mathrm{C}$ by injecting a first series of hydrogen pulses $\left(0.267 \mathrm{~cm}^{3}\right)$ up to saturation (HC1). The low temperature of chemisorption was required to suppress hydrogen spillover on the support [21]. A second series of pulses was injected over the sample, after 10 min of purging under pure Ar, to determine the reversible part of chemisorbed hydrogen (HC2). The irreversible part was taken as $\mathrm{HC}=\mathrm{HC} 1-\mathrm{HC} 2$.

Temperature Programmed Reduction (TPR) experiments were performed in a Micromeritics AutoChem II apparatus. Before analysis, the samples ( 200 mg) were treated under flowing oxygen from RT to $500{ }^{\circ} \mathrm{C}$ for $30 \mathrm{~min}$ with the heating rate of $10^{\circ} \mathrm{C} \mathrm{min}^{-1}$. Catalysts were then cooled down to RT under $\mathrm{O}_{2}\left(30 \mathrm{~mL} \cdot \mathrm{min}^{-1}\right)$ and outgassed under argon for $30 \mathrm{~min}$ (30 $\left.\mathrm{mL} \cdot \mathrm{min}^{-1}\right)$. Finally TPR was performed from RT up to $1000{ }^{\circ} \mathrm{C}$ at a rate of $5{ }^{\circ} \mathrm{C} \min ^{-1}$ for 30 min under $1 \% \mathrm{H}_{2} / \mathrm{Ar}\left(30 \mathrm{~mL} \mathrm{~min}^{-1}\right)$. $\mathrm{H}_{2}$ consumption was quantified by gas chromatography using a Thermal Conductivity Detector (TCD).

X-ray diffraction measurements were performed at room temperature in a Bruker AXS D5005 $\mathrm{X}$-ray diffractometer, working with $\mathrm{CuK} \alpha$ radiation $(\lambda=1.54184 \AA)$, generated at $40 \mathrm{kV}$ and $40 \mathrm{~mA}$. Signal is recorded for $2 \theta$ between $15^{\circ}$ and $85^{\circ}$ with a step of $0.04^{\circ}$ and a step time of 6 s. For sample identification, diffraction patterns were compared to the ICDD (International Center for Diffraction Data) database integrated in the EVA software. The crystallite size was calculated using the Debye-Scherrer equation. 


\subsection{Catalytic test}

The model feed of gasoline exhaust gas, given by PSA Peugeot Citroën Group, contains 2.2 vol. $\%$ of isooctane, 13.5 vol. \% of $\mathrm{CO}_{2}, 12 \mathrm{vol} . \%$ of $\mathrm{H}_{2} \mathrm{O}, 1$ vol.\% of $\mathrm{O}_{2}$ and 71.3 vol.\% of $\mathrm{N}_{2}$ (REGR conditions). Anhydrous isooctane $\left(\mathrm{C}_{8} \mathrm{H}_{18}\right)$ was supplied by Carlo Erba (99.5\%); $\mathrm{CO}_{2}$, $\mathrm{O}_{2}$ and $\mathrm{N}_{2}$ were provided by Air Liquide. Ultra pure water was used. The total gas flow rate was $250 \mathrm{Ncm}^{3} \mathrm{~min}^{-1}$

Reforming of exhaust gas recirculation (REGR) reaction was carried out in a quartz tubular continuous flow reactor. The catalyst $(150 \mathrm{mg})$ was activated under the REGR conditions, i.e. in the presence of all the reactants, or under hydrogen, by heating with a ramp of $10^{\circ} \mathrm{C} \mathrm{min}^{-1}$, from $130^{\circ} \mathrm{C}$ to the reaction temperature. The experiments were performed at $580^{\circ} \mathrm{C}$, with a total pressure of 1.3 bar and a weight hourly space velocity of $138 \mathrm{~h}^{-1}$, which corresponds to a gas hourly space velocity of roughly $150000 \mathrm{~h}^{-1}$, considering an average density of the solids of 1.5 $\mathrm{g} \mathrm{mL}^{-1}$. The experimental details for the experiments in the tubular continuous flow reactor are given in details in [12].

The catalyst performances were characterized by:

- The product yield :

$$
Y_{x}=\frac{F_{x}^{\text {out }}}{F_{C_{8} H_{18}}^{\text {in }}}
$$

Where $F_{C_{8} H_{18}}^{i n}$ is the molar flow rate of isooctane at the inlet of the reactor and $F_{x}^{\text {out }}$ the molar flow rate of the product $\mathrm{x}$ at the outlet

- The isooctane, oxygen, carbon dioxide and water conversion, in \% (example for isooctane)

$$
X_{C_{8} H_{18}}=\frac{F_{C_{8} H_{18}}^{\text {in }}-F_{C_{8} H_{18}}^{\text {out }}}{F_{C_{8} H_{18}}^{\text {in }}} \times 100
$$


Experimental values are compared to the values at the thermodynamic equilibrium obtained by calculation based on the minimization of the Gibbs free energy.

\section{Results and discussion}

\subsection{Characteristics of the catalysts}

The characteristics of the supports and of the catalysts in terms of surface area, volume and size of pores are reported in Table 1. Supports present BET surface area between $34(\mathrm{Al}(20) \mathrm{Ce}(80))$ and $256 \mathrm{~m}^{2} \mathrm{~g}^{-1}\left(\mathrm{CeO}_{2}\right)$. The introduction of rhodium, followed by activation treatments, leads to a slight decrease of the BET surface, except on $\mathrm{CeO}_{2}$ support, for which the specific surface area significantly decreases to $42 \mathrm{~m}^{2} \mathrm{~g}^{-1}$. This is due to the fact that the $\mathrm{CeO}_{2}$ support was not calcined, before introduction of rhodium. When cerium is added to aluminium oxide, it can be seen (Fig. 2) that the BET surface of the Rh/AlCex catalysts decreases from 175 to less than 50 $\mathrm{m}^{2} \mathrm{~g}^{-1}$.

XRD patterns are displayed in Fig.3. $\gamma-\mathrm{Al}_{2} \mathrm{O}_{3}$ (ICDD ${ }^{\circ}$ 00-029-0063) is clearly identified on the $\mathrm{Rh} / \mathrm{Al}_{2} \mathrm{O}_{3}$ pattern. The cell parameter $(\mathrm{a}=0.791 \mathrm{~nm})$, experimentally determined from the most intense peak $\left(2 \theta=66.9^{\circ}\right)$, corresponds to the $(4,4,0)$ plane. The crystallite size is estimated at $\sim 9.9 \mathrm{~nm}$. $\mathrm{Rh} / \mathrm{CeO}_{2}$ presents sharp diffraction lines corresponding to cerianite ceria (ICDD $\mathrm{n}^{\circ}$ 00-043-1002) crystallizing in a fluorite type fcc structure, with a crystallite size of $25.6 \mathrm{~nm}$. $\mathrm{Rh} / \mathrm{Al}(80) \mathrm{Ce}(20)$ presents both type of ceria and alumina phases, which indicates that cerium is not incorporated in the alumina structure. The XRD pattern of $\mathrm{Rh} / \mathrm{Al}(20) \mathrm{Ce}(80)$ shows only peaks characteristic of ceria, showing that alumina is likely to be amorphous. The cell parameters of $\mathrm{Rh} / \mathrm{Al}(80) \mathrm{Ce}(20)$ and $\mathrm{Rh} / \mathrm{Al}(20) \mathrm{Ce}(80)$, are $0.539 \mathrm{~nm}$ and $0.540 \mathrm{~nm}$, similar to ceria (cerianite), and the mean crystallite size of the pseudo-cerianite phase of $21.6 \mathrm{~nm}$ and 27.3 $\mathrm{nm}$, respectively. $\mathrm{Rh} / \mathrm{CeZrAl}$ presents diffraction lines typical of $\mathrm{Ce}_{0.5} \mathrm{Zr}_{0.5} \mathrm{O}_{2}$ (ICDD n ${ }^{\circ} 00$ 038-1436), showing that the alumina added to this support is amorphous and does not modify 
the oxide structure. In $\mathrm{Rh} / \mathrm{CeZrAl}, \mathrm{CeZr}$ is a homogeneous solid solution with a mean crystallite size of $18.7 \mathrm{~nm}$, and cell parameters $(\mathrm{a}=\mathrm{b}=0.372 \mathrm{~nm} ; \mathrm{c}=0.527 \mathrm{~nm}$ ) similar to the ICDD (a $=\mathrm{b}=0.372 \mathrm{~nm} ; \mathrm{c}=0.530 \mathrm{~nm})$.

TPR profiles of the $\mathrm{Al}(\mathrm{Cex})$ series and $\mathrm{CeZrAl}$, are presented in Fig.3 and the results detailed in Table 2. No peak is observed on the alumina support, due to the non-reducibility of this support. It can be seen in Fig. 3 that $\mathrm{CeO}_{2}$ presents a first reduction peak with a maximum at $371^{\circ} \mathrm{C}$ and a second one, starting at $660^{\circ} \mathrm{C}$. The first peak may be attributed to the reduction of surface $\mathrm{Ce}^{4+}$. Generally, $\mathrm{CeO}_{2}$ presents two peaks during the reduction process : a first one, around $400^{\circ} \mathrm{C}$, attributed to surface reduction and the second one, above $750^{\circ} \mathrm{C}$, corresponding to the reduction of the bulk $[22,23]$. It can be seen in Table 2 that only $7 \%$ of ceria is reduced at the first peak attributed to surface ceria, which is little and may be attributed to the low temperature of this first reduction peak. Mixed $\mathrm{Al}(80) \mathrm{Ce}(20)$ and $\mathrm{Al}(20) \mathrm{Ce}(80)$ supports start to be reduced at temperatures higher than that of $\mathrm{CeO}_{2}$, with a first maximum of reduction peak 538 and $580^{\circ} \mathrm{C}$, respectively, attributed to the reduction of surface ceria, and a second one at 986 and $990^{\circ} \mathrm{C}$ to bulk ceria, in accordance with the results obtained by Yao et al. [22] on the same type of support. For $\mathrm{Al}(80) \mathrm{Ce}(20)$, total consumption of hydrogen is similar to the theoretical one, indicating that all ceria has been reduced. On the contrary, the experimental one for $\mathrm{Al}(20) \mathrm{Ce}(80)(1303 \mu \mathrm{mol} / \mathrm{g})$ is much lower than the theoretical one , which may be explained, by the desorption of hydrogen as for pure $\mathrm{CeO}_{2}$, or by an incomplete reduction of $\mathrm{Ce}^{4+}$. For $\mathrm{CeZrAl}$, two peaks are observed with maxima at $657^{\circ} \mathrm{C}$ and at $1088^{\circ} \mathrm{C}$, whereas it is known that the presence of $\mathrm{Zr}$ allows starting the reduction of $\mathrm{Ce}^{4+}$ at lower temperature [24].This different behaviour may be explained by the presence of $10 \mathrm{wt} \%$ of $\mathrm{Al}_{2} \mathrm{O}_{3}$ that may hinder the reduction of $\mathrm{Ce}_{0.5} \mathrm{Zr}_{0.5} \mathrm{O}_{2}$. However, the first peak $\left(657^{\circ} \mathrm{C}\right)$, which may be attributed to the surface reduction, corresponds to $26 \%$ of the total consumption, which is much higher than that observed for the $\mathrm{Al}(\mathrm{Cex})$ series $(3 \%-7 \%)$. Consequently, the first peak most probably 
corresponds to the reduction of ceria surface and subsurface [24]. As for $\mathrm{Al}(80) \mathrm{Ce}(20)$, the reduction of $\mathrm{CeO}_{2}$ is complete, with an experimental total $\mathrm{H}_{2}$ consumption similar to the theoretical one .

Fig.4 displays the TPR profile of the catalysts after impregnation of $\mathrm{Rh}(1 \mathrm{wt} \%)$. Compared to the bare supports (Fig.4) the presence of the metal favours the reduction of $\mathrm{Ce}^{4+}$. Two domains of temperature can be identified. In the first one $\left(\mathrm{T}<350^{\circ} \mathrm{C}\right)$, the first reduction peak in the $120-244^{\circ} \mathrm{C}$ range, is attributed to the simultaneous reduction of $\mathrm{Rh}_{2} \mathrm{O}_{3}$ and of the surface ceria, the presence of the metal favouring the spillover of hydrogen towards the support. It can be seen that, except for $\mathrm{Rh} / \mathrm{Al}(20) \mathrm{Ce}(80)$ presenting the lowest temperature of reduction, the temperature of the maximum of the first peak decreases as the cerium content increases. In the second part $\left(\mathrm{T}>350^{\circ} \mathrm{C}\right)$, the reduction of bulk ceria can occur. The experimental amount of hydrogen consumed in the first domain $\left(\mathrm{T}<350^{\circ} \mathrm{C}\right)$ and $\mathrm{H}_{2} / \mathrm{Rh}$ molar ratio are reported in Table 3 for each catalyst. Considering the total oxidation of $\mathrm{Rh}$ to $\mathrm{Rh}_{2} \mathrm{O}_{3}$ during the oxidizing pretreatment, the total reduction of this oxide must correspond to a consumption of $146 \mu \mathrm{mol} \mathrm{H}_{2}$ $\mathrm{g}^{-1}$, and $\mathrm{H}_{2} / \mathrm{Rh}=1.5$. Except for $\mathrm{Rh} / \mathrm{Al}_{2} \mathrm{O}_{3}$, this molar ratio is superior to 1.5 , due to the reduction of surface $\mathrm{CeO}_{2}$ (spillover), which occurs at low temperature. This phenomenon is particularly noticeable for $\mathrm{Rh} / \mathrm{CeZrAl}\left(\mathrm{H}_{2} / \mathrm{Rh}=6.1\right)$. The low $\mathrm{H}_{2}$ consumption for $\mathrm{Rh} / \mathrm{Al}_{2} \mathrm{O}_{3}$ is due to the calcination temperature of $650^{\circ} \mathrm{C}$. It is known that, when $\mathrm{Rh} / \mathrm{Al}_{2} \mathrm{O}_{3}$ is oxidized at temperatures higher than $600^{\circ} \mathrm{C}, \mathrm{Rh}^{3+}$ easily diffuses into the spinel structure of $\gamma \mathrm{Al}_{2} \mathrm{O}_{3}$ and is then difficult to reduce [25-28].

All the catalysts, except $\mathrm{Rh} / \mathrm{CeO}_{2}$, present a metal dispersion of roughly $40 \%$, corresponding to a particle size of $\sim 22 \AA$ (table 4). The low dispersion of $\mathrm{Rh} / \mathrm{CeO}_{2}(18 \%)$ is attributed to the support sintering, which occurs during the calcination process, leading to a drastic decrease of the BET surface area (from 256 to $42 \mathrm{~m}^{2} \mathrm{~g}^{-1}$, Table 1 ). 


\subsection{Catalytic performances}

The composition of the gas phase in the reforming conditions using isooctane as model molecule are summarized in Table 5 along with the one obtained after a blank test, i.e. a reaction in the standard conditions but without any catalyst. It can be seen that without catalyst, $6 \%$ of $\mathrm{C}_{8} \mathrm{H}_{18}$ and $\sim 100 \%$ of $\mathrm{O}_{2}$ are converted, and the reaction products are $\mathrm{CO}\left(0.24 \mathrm{~mol} / \mathrm{mol} \mathrm{C}_{8} \mathrm{H}_{18}\right)$, $\mathrm{H}_{2}\left(0.27 \mathrm{~mol} / \mathrm{mol} \mathrm{C}_{8} \mathrm{H}_{18}\right), \mathrm{CO}_{2}\left(0.23 \mathrm{~mol} / \mathrm{mol} \mathrm{C}_{8} \mathrm{H}_{18}\right)$ and $\mathrm{H}_{2} \mathrm{O}\left(\approx 0.3 \mathrm{~mol} / \mathrm{mol} \mathrm{C}_{8} \mathrm{H}_{18}\right)$. It can be noticed that without $\mathrm{O}_{2}$ in the gas phase, no conversion is observed, which indicates that the only reaction occurring without catalyst is an oxidation reaction. Thus the reaction products are obtained by oxidation, and as $\mathrm{H}_{2} / \mathrm{CO}$ is equal to 1.12 , it can be inferred that $\mathrm{H}_{2}$ is produced by isooctane partial oxidation, according to the reaction (Eq. (5)):

$\mathrm{C}_{8} \mathrm{H}_{18}+4 \mathrm{O}_{2} \rightarrow 8 \mathrm{CO}+9 \mathrm{H}_{2}$

However, total oxidation also occurs since $\mathrm{H}_{2} \mathrm{O}$ and $\mathrm{CO}_{2}$ are produced. Some other products were also detected but in small amounts $\left(<0.01 \mathrm{~mol} / \mathrm{mol} \mathrm{C}_{8} \mathrm{H}_{18}\right)$, such as ethylene, propylene, isobutene and $\mathrm{C} 7 \mathrm{C} 8$ products.

Fig. 6 shows the typical evolution of the conversion and products distribution obtained in the presence of a Rh-supported catalyst, when the catalyst is activated in situ by reduction under hydrogen before the catalytic test. The conversion of isooctane and water is not total and decreases as a function of time-on -stream (TOS), which leads to a slight decrease in the yield of products. Moreover, as observed for blank reaction, other products, such as C2-C4 and C7C8 hydrocarbons are produced in small amounts $\left(<0.1 \mathrm{~mol} / \mathrm{mol} \mathrm{C}_{8} \mathrm{H}_{18}\right)$.

When the catalyst is activated by heating up to $580^{\circ} \mathrm{C}$ under the reaction conditions, i.e. in the presence of all the reactants instead of pure hydrogen, the conversion of isooctane and water is noticeably decreased (Table 6), which causes a decrease in the formation of all the products and especially $\mathrm{H}_{2}$. This loss of performance may be due to an incomplete reduction of rhodium or to a deactivation of the catalyst that can start before the temperature of $580^{\circ} \mathrm{C}$ is reached. 
However, as the pretreatment under reaction conditions is more realistic and closer to the REGR conditions, all the results presented hereafter were obtained after such a pretreatment.

The yields in $\mathrm{H}_{2}$ obtained for the $\mathrm{Rh} / \mathrm{Al}(\mathrm{Cex})$ series and for $\mathrm{Rh} / \mathrm{CeZrAl}$ catalyst are reported in Fig. 7 as a function of TOS, and the complete results obtained after $7 \mathrm{~h}$ of TOS are summarized in Table 7. $\mathrm{Rh} / \mathrm{Al}_{2} \mathrm{O}_{3}$ is the less efficient catalyst in terms of isooctane conversion and $\mathrm{H}_{2}$ production. $\mathrm{Rh} / \mathrm{CeO}_{2}$ allows obtaining high initial yield in $\mathrm{H}_{2}$ but deactivates rapidly. Catalysts containing $\mathrm{Al}_{2} \mathrm{O}_{3}$ and $\mathrm{CeO}_{2}, \mathrm{Rh} / \mathrm{Al}(80) \mathrm{Ce}(20)$ and $\mathrm{Rh} / \mathrm{Al}(20) \mathrm{Ce}(80)$, present higher performances than $\mathrm{Rh}$ supported on single oxides, with an initial yield in $\mathrm{H}_{2}\left(\sim 6.5 \mathrm{~mol} \mathrm{H}_{2} / \mathrm{mol}\right.$ $\mathrm{C}_{8} \mathrm{H}_{18}$ ) similar to the one obtained with $\mathrm{Rh} / \mathrm{CeO}_{2}$ but a superior stability. The addition of zirconium to the $\mathrm{Ce}-\mathrm{Al}$ support improves the initial yield in $\mathrm{H}_{2}\left(7.3 \mathrm{~mol} \mathrm{H}_{2} / \mathrm{mol} \mathrm{C}_{8} \mathrm{H}_{18}\right)$, but it decreases rapidly to reach the one observed with $\mathrm{Al}(80) \mathrm{Ce}(20)$ and $\mathrm{Al}(20) \mathrm{Ce}(80)$. Results summarized in Table 7 show that, whatever the catalyst, a complete conversion of isooctane is never reached and the best yields in $\mathrm{H}_{2}$, obtained after $7 \mathrm{~h}$ of TOS with catalysts containing both ceria and alumina $(\mathrm{Rh} / \mathrm{Al}(80) \mathrm{Ce}(20), \mathrm{Rh} / \mathrm{Al}(20) \mathrm{Ce}(80), \mathrm{CeZrAl})$ are below the value predicted by calculation at the thermodynamic equilibrium. It can also be seen that the amount of methane produced is very small, much lower than the value predicted by the thermodynamic calculation. During the reaction in the REGR conditions, methane may be produced by isooctane decomposition or hydrogenolysis or by methanation of $\mathrm{CO}$ or $\mathrm{CO}_{2}$ [13], and then consumed by steam or dry reforming. All these steps were studied in details in [13] and it was demonstrated that the low amount of methane is due to the limitation of its formation, isooctane decomposition and hydrogenolysis and $\mathrm{CO}_{2}$ methanation being strongly disfavored in the reaction conditions in the presence of a Rh-based catalyst. On this type of catalyst, methane is nearly exclusively produced by CO hydrogenation. Whatever the support, the conversion of $\mathrm{H}_{2} \mathrm{O}$ is $\sim 50 \%$, whereas $\mathrm{CO}_{2}$ conversion is $\sim 0$. One can note that a negative conversion indicates that the amount of $\mathrm{CO}_{2}$ produced is higher than its consumption. 
In order to understand the origin of the deactivation observed during the catalytic tests, the metal dispersion was evaluated at the end of the catalytic test. Results are reported in Figure 8 where they are compared to the initial metal dispersion. It can be seen that, whatever the support, a decrease in metal dispersion is observed during the reaction. This effect is more pronounced for $\mathrm{CeO}_{2}$, for which the metal dispersion dropped from $18 \%$ to $4 \%$ (variation $\Delta=$ $77 \%$ ). Consequently, for this catalyst, the metal-support interaction is rather low and does not allow limiting the metal sintering. Supports containing mainly alumina $\left(\mathrm{Al}_{2} \mathrm{O}_{3}\right.$ and $\mathrm{Al}(80) \mathrm{Ce}(20))$ present a dispersion drop of $30 \%$, whereas those containing more ceria, $\mathrm{Al}(20) \mathrm{Ce}(80)$ and $\mathrm{CeZrAl}$ a one of $23 \%$ (Fig.8a). Rh sintering is probably due to the presence of steam at relatively high temperature, as proposed in [29] for $\mathrm{Pt} / \mathrm{CeZrO}_{2}$ catalyst. It can be seen from Fig. $8 \mathrm{~b}$ that the conversion of $\mathrm{C}_{8} \mathrm{H}_{18}$ is directly related to the metal dispersion before and after catalytic test. Although all the rhodium supports are different, the higher the metal dispersion, the higher the $\mathrm{C}_{8} \mathrm{H}_{18}$ conversion. For this series of catalysts, the support does not play a direct role in the reaction but an indirect one, on the metal dispersion. These results also show that the deactivation may be related to the loss in metal dispersion. The effect of particle size has been demonstrated on the methane steam reforming reaction, the reaction rate per active site increasing with the dispersion on many metal catalysts, including rhodium [30]. However, an opposite result was obtained with $\mathrm{Ni} / \mathrm{CeZrO}_{2}$ for the autothermal reforming (ATR), i.e. the steam reforming in the presence of oxygen, of isooctane [31]. Indeed, it was demonstrated by varying the particle size but keeping the number of active sites constant, that the yield in $\mathrm{CO}$ and $\mathrm{H}_{2}$ is higher on largest particles, which may be explained either (i) by the fact that isooctane is a large molecule needing large metal ensembles to be adsorbed or (ii) or by the ability of small $\mathrm{Ni}$ particles to be oxidized in the ATR conditions, leading to a loss of active sites. In fact, it was demonstrated on $\mathrm{Ni} / \mathrm{Al}_{2} \mathrm{O}_{3}$ for isooctane conversion by partial oxidation [32] that active catalysts need to be both well dispersed and highly reducible, which 
are two opposite tendencies. This explanation seems valid for the Rh catalysts of the present study.

\section{Conclusion}

Rh catalysts supported on alumina, ceria or oxides containing both ceria and alumina were used for producing hydrogen in the presence of isooctane, used as model molecule of gasoline fuel, and various gases representative of vehicle exhaust gases. The best results in terms of conversion, stability, and yield in hydrogen were obtained on catalysts containing both ceria and alumina, namely $\mathrm{CeO}_{2}-\mathrm{Al}_{2} \mathrm{O}_{3}(\mathrm{Al}(20$ or 80$) \mathrm{Ce}(80$ or 20$))$ and $\mathrm{Ce}_{0.5} \mathrm{Zr}_{0.5} \mathrm{O}_{2}-\mathrm{Al}_{2} \mathrm{O}_{3}(\mathrm{CeZrAl})$ supports. These better performances were directly linked to the higher initial $\mathrm{Rh}$ dispersion obtained on this type of supports as well as to the higher stability, due to lower metal sintering during the catalytic test. This metal sintering was less important for the supports containing the highest amount of cerium $(\mathrm{Al}(20) \mathrm{Ce}(80)$ and $\mathrm{CeZrAl})$ and the role of alumina is to improve the thermal stability of the support.

\section{ACKNOWLEDGEMENTS}

ADEME (PREDIT Program nº 0606 C0137) is gratefully acknowledged for financial support.

\section{REFERENCES}

[1] H. Wei, T. Zhu, G. Shu, L. Tan, Y. Wang, Applied energy, 99 (2012) 534-544.

[2] Y. Jamal, T. Wagner, M. L. Wyszynski, Int. J. Hydrogen Energy, 21 (1996) 507-519.

[3] M. L. Wyszynski and Y. Jamal, Int. J. Hydrogen Energy, 7 (1994) 557-572. 
[4] S. Peucheret, M. L. Wyszynski, R. S. Lehrle, S. Golunski, H. Xu, Int. J. Hydrogen Energy, 30 (2005) 1583-1594.

[5] A. Tsolakis, A. Megaritis, D. Yap, Energy, 33 (2008) 462-470.

[6] A. Tsolakis, A. Megaritis, M.L. Wyszynski, K. Theinnoi, Energy, 32 (2007) 2072-2080.

[7] D. Fennel, J. Herreros, A. Tsolakis, Int. J. Hydrogen Energy, 39 (2014) 5153-5162.

[8] R. Stone, H.Y. Zhao, L. Zhou, SAE Technical paper N²010-01-0580 (2010)

[9] S. Peucheret, M. Feaviour, S. Golunski, Appl. Catal., B 65 (2006) 201-206.

[10] E. Ambroise, C. Courson, A. Kiennemann, A.-C. Roger, O. Pajot, E. Samson, G. Blanchard, Top. Catal., 52 (2009) 2101-2107.

[11] E. Ambroise, C. Courson, A.-C. Roger, A. Kiennemann, G. Blanchard, S. Rousseau, X. Carrier, E. Marceau, C. La Fontaine, F. Villain, Catal. Today, 154 (2010) 133-141.

[12] S. Rijo Gomes, N. Bion, G. Blanchard, S. Rousseau, V. Bellière-Baca, V. Harlé, D. Duprez, F. Epron, Appl. Catal. B, 102 (2011) 44-53.

[13] S. Rijo Gomes, N. Bion, G. Blanchard, S. Rousseau, D. Duprez, F. Epron, RSC Advances, 1 (2011) 109-116.

[14] R. M. Navarro Yerga, M. C. Alvarez-Galvan, N. Mota, J. A. Villoria de la Mano, S. M. Al-Zahrani, J. L. G. Fierro, ChemCatChem, 3 (2011) 440 - 457.

[15] A. Holmgren, D. Duprez, B. Andersson, J. Catal., 182 (1999) 441-448.

[16] D. Andreeva, I. Ivanov, L. Ilieva, M.V. Abrashev, Appl. Catal.A, 302 (2006) 127-132

[17] J. Fonseca, S. Royer, N. Bion, L. Pirault-Roy, M. C. Rangel, D. Duprez, F. Epron, Appl. Catal. B., 128 (2012) 10-20.

[18] P Fornasiero, R. Dimonte, G. R Rao, J. Kaspar, S. Meriani, A. Trovarelli, M. Graziani, J. Catal., 151 (1995) 168-177.

[19] A. Tsolakis, S. E. Golunski, Chem.Eng. J., 117 (2006) 131-136.

[20] B. E. Yoldas, U.S patent 3941719, (1976) 
[21] S. Bernal, F.J. Botana, J.J. Calvino, M.A. Cauqui, G.A. Cifredo, A.Jobacho, J.M. Pintado, J.M. Rodriguez-Iquierdo, J. Phys. Chem. 97 (1993) 4118-4123.

[22] H. C. Yao, Y. F. Y. Yao, J. Catal., 86 (1984) 254-265.

[23] C. Leitenburg, A. Trovarelli, J. Kaspar, J. Catal., 166 (1997) 98-107.

[24] K. Otsuka, Y. Wang, M. Nakamura, Appl. Catal.A: Gen., 183 (1999) 317-324.

[25] T. Wang, L. D. Schmidt, J. Catal., 71 (1981) 411-422.

[26] H. C Yao, H. K. Stepien, H. S. Gandhi, J. Catal., 61 (1980) 547-550.

[27] D. D. Beck, C. J. Carr, J. Catal., 144 (1993) 296-310.

[28] J. Barbier Jr, D. Duprez, Appl. Catal. B: Environ., 4 (1994) 105-140.

[29] L. Villegas, N. Guilhaume, H. Provendier, C. Daniel, F. Masset, C. Mirodatos, Appl. Catal. A: Gen., 281 (2005) 75-83.

[30] G. Jones, J.G. Jakobsen, S.S. Shim, J. Kleis, M.P. Andersson, J. Rossmeisl, F. AbildPederson, T. Bligaards, S. Helveg, B. Hinnemann, J.R. Rostrup-Nielsen, I. Chorkendorff, J. Sehested, J.K. Nørskov, J. Catal., 259 (2008) 147-160.

[31] J.M. Mayne, K. A. Dahlberg, T. A. Westrich, A. R. Tadd, J. W. Schwank, Appl. Catal. A: Gen., 400 (2011) 203-214.

[32] H. H. Ibrahim, P. Kumar, R.O. Idem, Energy \& Fuels 21 (2007) 570-580. 
Table 1 : Surface area of catalysts and supports and volume and size of pores for the supports.

\begin{tabular}{|c|c|c|c|}
\hline Supports and catalysts & $\begin{array}{c}\text { BET surface } \\
\text { area }\left(\mathrm{m}^{2} / \mathrm{g}\right)\end{array}$ & $\begin{array}{c}\text { Volume of } \\
\text { pores } \\
\left(\mathrm{cm}^{3} / \mathrm{g}\right)\end{array}$ & $\begin{array}{c}\text { Size of pores } \\
(\AA)\end{array}$ \\
\hline $\mathrm{Al}_{2} \mathrm{O}_{3}$ & 184 & 0.49 & 108 \\
\hline $\mathbf{R h} / \mathrm{Al}_{2} \mathrm{O}_{3}$ & 175 & - & - \\
\hline $\mathrm{CeO}_{2}$ a & 256 & 0.17 & 147 \\
\hline $\mathrm{Rh} / \mathrm{CeO}_{2}$ & 42 & - & - \\
\hline $\operatorname{Al}(80) \operatorname{Ce}(20)$ & 103 & 0.32 & 124 \\
\hline Rh/Al(80)Ce(20) & 102 & - & - \\
\hline $\operatorname{Al}(20) \operatorname{Ce}(80)$ & 34 & 0.07 & 76 \\
\hline Rh/Al(20)Ce(80) & 29 & - & - \\
\hline CeZrAl & 66 & 0.20 & 125 \\
\hline Rh/CeZrAl & 57 & - & - \\
\hline
\end{tabular}

${ }^{\text {a }}$ not calcined

Table 2: TPR results of $\mathrm{Al}(\mathrm{Cex})$ series and CeZrAl.

\begin{tabular}{|c|c|c|c|c|c|c|c|}
\hline \multirow{2}{*}{ Support } & \multirow{2}{*}{$\begin{array}{c}\mathrm{CeO}_{2} \\
(\mathrm{wt} \%)\end{array}$} & \multirow{2}{*}{$\begin{array}{c}\text { Theo. } \mathrm{H}_{2} \\
\text { consumption } \\
\text { for } \mathrm{CeO}_{2}\end{array}$} & \multicolumn{2}{|c|}{$\mathbf{T}_{\max }$} & \multicolumn{2}{|c|}{ Exp. $\mathrm{H}_{2}$ consumption } & \multirow{2}{*}{$\begin{array}{c}\begin{array}{c}\% \text { of } \\
\text { reduction of } \\
\text { surface } \mathrm{Ce}^{4+} \\
\text { to } \mathrm{Ce}^{3+\mathrm{a}}\end{array} \\
\text { pic } 1(\%)\end{array}$} \\
\hline & & & $\begin{array}{l}\text { pic } 1 \\
\left({ }^{\circ} \mathbf{C}\right)\end{array}$ & $\begin{array}{l}\text { pic } 2 \\
\left({ }^{\circ} \mathbf{C}\right)\end{array}$ & $\begin{array}{c}\text { TOTAL } \\
\left(\mu \mathrm{mol} \mathrm{H}_{2} / \mathrm{g}\right)\end{array}$ & $\begin{array}{c}\text { pic 1 } \\
\left(\mu \mathrm{mol} \mathbf{H}_{2} / \mathrm{g}\right)\end{array}$ & \\
\hline $\mathrm{Al}_{2} \mathrm{O}_{3}$ & $0 \%$ & - & - & - & - & - & - \\
\hline $\mathrm{CeO}_{2}$ & $100 \%$ & 2905 & 371 & 1025 & $-b$ & 217 & $7 \%$ \\
\hline $\mathrm{Al}(80) \mathrm{Ce}(20)$ & $20 \%$ & 581 & 538 & 986 & 634 & 40 & $7 \%$ \\
\hline $\mathrm{Al}(20) \mathrm{Ce}(80)$ & $80 \%$ & 2324 & 580 & 990 & 1303 & 75 & $3 \%$ \\
\hline CeZrAl & $51.9 \%$ & 1508 & 657 & 1088 & 1572 & 399 & $26 \%$ \\
\hline
\end{tabular}

${ }^{a}$ calculated from the theoretical value

${ }^{\mathrm{b}}$ consumption not finished at the end of the experiment 
Table 3 : Amount of $\mathrm{H}_{2}$ consumption and $\mathrm{H}_{2} / \mathrm{Rh}$ molar ratio at the first reduction peak $\left(\mathrm{T}_{\max }<\right.$ $\left.350^{\circ} \mathrm{C}\right)$

\begin{tabular}{|c|c|c|}
\hline $\begin{array}{c}\text { Reduction at } \mathbf{T}_{\max }< \\
350^{\circ} \mathrm{C}\end{array}$ & $\begin{array}{c}\text { Exp. } \mathrm{H}_{2} \text { cons. } \\
\left(\mu \mathrm{mol} \mathrm{H}_{2} / \mathrm{g}\right)\end{array}$ & $\begin{array}{c}\mathrm{H}_{2} / \mathrm{Rh} \\
(\mathrm{mol} / \mathrm{mol})\end{array}$ \\
\hline $\mathrm{Rh} / \mathrm{Al}_{2} \mathrm{O}_{3}$ & 51 & 0.5 \\
\hline $\mathrm{Rh} / \mathrm{CeO}_{2}$ & 369 & 3.8 \\
\hline $\operatorname{Rh} / \operatorname{Al}(80) \operatorname{Ce}(20)$ & 160 & 1.6 \\
\hline $\operatorname{Rh} / \operatorname{Al}(20) \operatorname{Ce}(80)$ & 252 & 2.6 \\
\hline Rh/CeZrAl & 595 & 6.1 \\
\hline
\end{tabular}

Table 4: metal contents, metal dispersion and metal particle size of $\mathrm{Rh} / \mathrm{Al}(\mathrm{Cex})$ and $\mathrm{Rh} / \mathrm{CeZrAl}$ catalysts.

\begin{tabular}{|c|c|c|c|}
\hline Catalysts & $\begin{array}{l}\text { Metal content } \\
\text { (ICP) }\end{array}$ & Dispersion $^{a}$ & 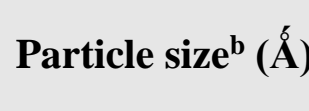 \\
\hline $\mathrm{Rh} / \mathrm{Al}_{2} \mathrm{O}_{3}$ & $1.10 \%$ & $39 \%$ & 24 \\
\hline $\mathrm{Rh} / \mathrm{CeO}_{2}$ & $1.01 \%$ & $18 \%$ & 51 \\
\hline $\mathrm{Rh} / \mathrm{Al}(80) \mathrm{Ce}(20)$ & $1.09 \%$ & $43 \%$ & 21 \\
\hline $\mathrm{Rh} / \mathrm{Al}(20) \mathrm{Ce}(80)$ & $1.03 \%$ & $42 \%$ & 22 \\
\hline $\mathrm{Rh} / \mathrm{CeZrAl}$ & $1.01 \%$ & $46 \%$ & 20 \\
\hline
\end{tabular}

a considering $\mathrm{H} / \mathrm{Rh}=1$

${ }^{\mathrm{b}}$ calculated from the dispersion value

Table 5 : Composition of the gas in the REGR condition and of the outlet gas (blank reaction without catalyst at $580^{\circ} \mathrm{C}, \mathrm{P}=1.3 \mathrm{bar}, \mathrm{WHSV}=137.8 \mathrm{~h}^{-1}$ )

\begin{tabular}{cccc}
\hline Component & $\begin{array}{c}\text { Inlet } \\
\text { composition } \\
(\mathbf{m o l} \%)\end{array}$ & $\begin{array}{c}\text { Inlet } \\
\text { composition } \\
(\mathbf{m o l} / \mathbf{m o l} \\
\mathbf{C 8 H 1 8 ~ 0 )}\end{array}$ & $\begin{array}{c}\text { Products after } \\
\text { blank reaction } \\
(\mathbf{m o l} / \mathbf{m o l} \\
\mathbf{C 8 H 1 8 0})\end{array}$ \\
\hline $\mathbf{C}_{8} \mathbf{H}_{18}$ & $2.2 \%$ & 1.00 & 0.94 \\
\hline $\mathbf{C O}_{2}$ & $13.5 \%$ & 6.15 & 6.38 \\
\hline $\mathbf{H}_{2} \mathbf{O}$ & $12.0 \%$ & 5.45 & 5.75 \\
\hline $\mathbf{O}_{2}$ & $1.0 \%$ & 0.45 & 0 \\
\hline $\mathbf{N}_{2}$ & $71.3 \%$ & 32.42 & 32.42 \\
\hline $\mathbf{H}_{2}$ & - & - & 0.27 \\
\hline $\mathbf{C O}$ & - & - & 0.24 \\
\hline $\mathbf{C H}_{4}$ & - & - & - \\
\hline
\end{tabular}


Table 6: Effect of the pretreatment on the distribution of products and conversion of reactants after $7 \mathrm{~h}$ of $\mathrm{TOS}$ for $\mathrm{Rh} / \mathrm{Al}_{2} \mathrm{O}_{3}$ various catalysts at $\mathrm{T}=580^{\circ} \mathrm{C}$ (activation by heating under reaction conditions or under $\mathrm{H}_{2}$ ).

\begin{tabular}{ccccccc}
\hline \multirow{2}{*}{ Activation } & \multicolumn{3}{c}{ Yield (mol/mol C8 $\mathbf{H}_{18 ~ 0)}$} & \multicolumn{3}{c}{ Conversion (\%) } \\
\cline { 2 - 7 } & $\mathbf{H}_{\mathbf{2}}$ & $\mathbf{C O}$ & $\mathbf{C H}_{\mathbf{4}}$ & $\mathbf{C}_{8} \mathbf{H}_{18}$ & $\mathbf{H}_{\mathbf{2}} \mathbf{O}$ & $\mathbf{C O}_{2}$ \\
\hline Thermo. & 7.3 & 6.4 & 2.6 & 100 & 64 & 16 \\
\hline $\mathrm{H}_{2}$ & 6.6 & 4.0 & 0.82 & 64 & 57 & -0.5 \\
\hline $\mathrm{C}_{8} \mathrm{H}_{18}+\mathrm{H}_{2} \mathrm{O}+\mathrm{CO}_{2}+\mathrm{O}_{2}$ & 5.6 & 2.9 & 0.14 & 39 & 47 & -5.0 \\
\hline
\end{tabular}

Table 7 : Distribution of products and conversion of reactants after $7 \mathrm{~h}$ of TOS for various catalysts at $\mathrm{T}=580^{\circ} \mathrm{C}$, activation by heating under reaction conditions.

\begin{tabular}{lcccccc}
\hline \multirow{2}{*}{ Catalysts } & \multicolumn{3}{c}{ Yield (mol/mol C8H18 0) } & \multicolumn{3}{c}{ Conversion (\%) } \\
\cline { 2 - 7 } & $\mathbf{H}_{\mathbf{2}}$ & $\mathbf{C O}$ & $\mathbf{C H}_{\mathbf{4}}$ & $\mathbf{C}_{\mathbf{8}} \mathbf{H}_{\mathbf{1 8}}$ & $\mathbf{H}_{\mathbf{2}} \mathbf{O}$ & $\mathbf{C O}_{\mathbf{2}}$ \\
\hline \multicolumn{1}{c}{ Thermo. } & 7.3 & 6.4 & 2.6 & 100 & 64 & 16 \\
\hline $\mathrm{Rh} / \mathrm{CeZrAl}$ & 6.5 & 3.4 & 0.58 & 57 & 48 & -0.8 \\
$\mathrm{Rh} / \mathrm{Al}(80) \mathrm{Ce}(20)$ & 6.6 & 3.8 & 0.42 & 53 & 54 & 1.3 \\
$\mathrm{Rh} / \mathrm{Al}(20) \mathrm{Ce}(80)$ & 6.5 & 3.7 & 0.60 & 54 & 50 & -2.0 \\
$\mathrm{Rh} / \mathrm{CeO}_{2}$ & 6.1 & 3.2 & 0.31 & 47 & 47 & -2.0 \\
$\mathrm{Rh} / \mathrm{Al}_{2} \mathrm{O}_{3}$ & 5.6 & 2.9 & 0.14 & 39 & 47 & -5.0 \\
\hline
\end{tabular}




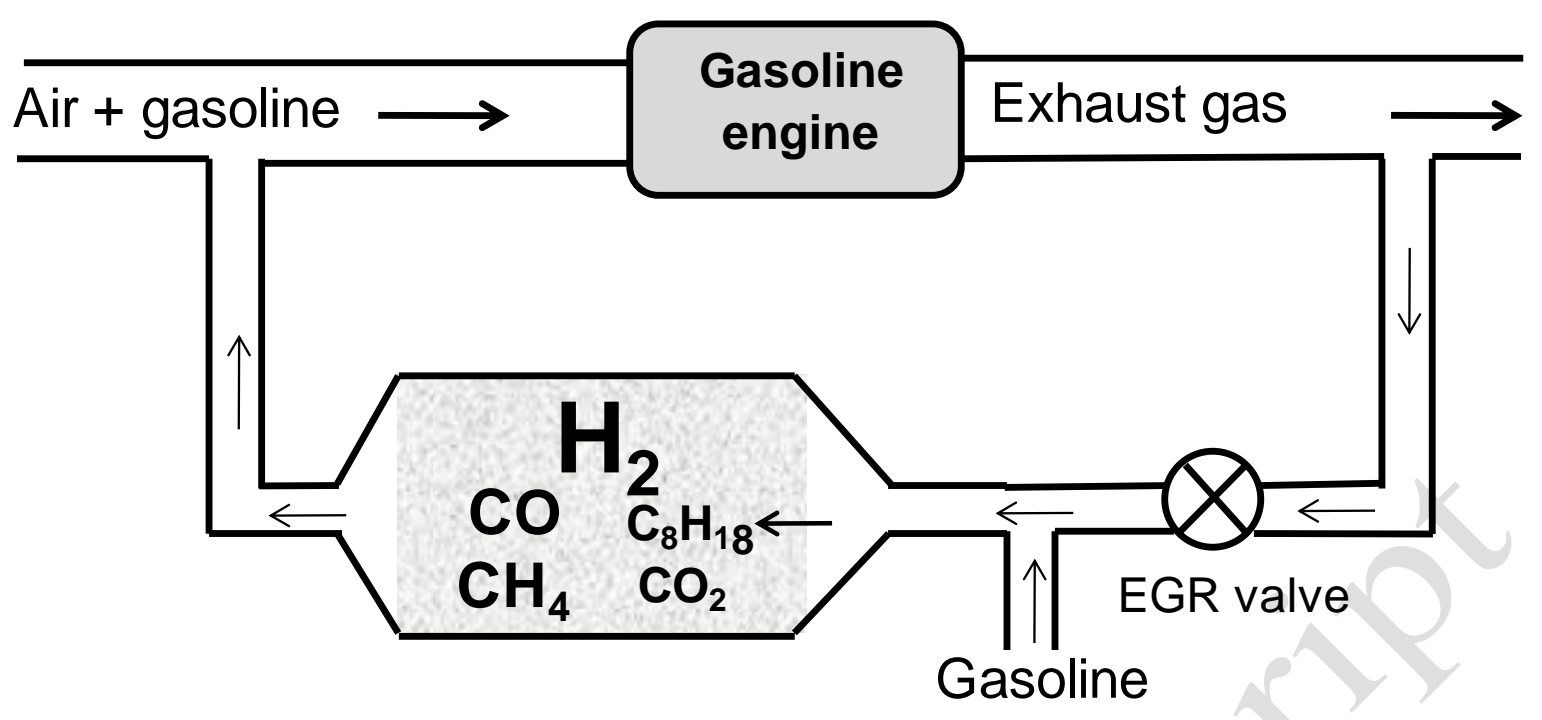

Figure 1 : Scheme of the REGR process

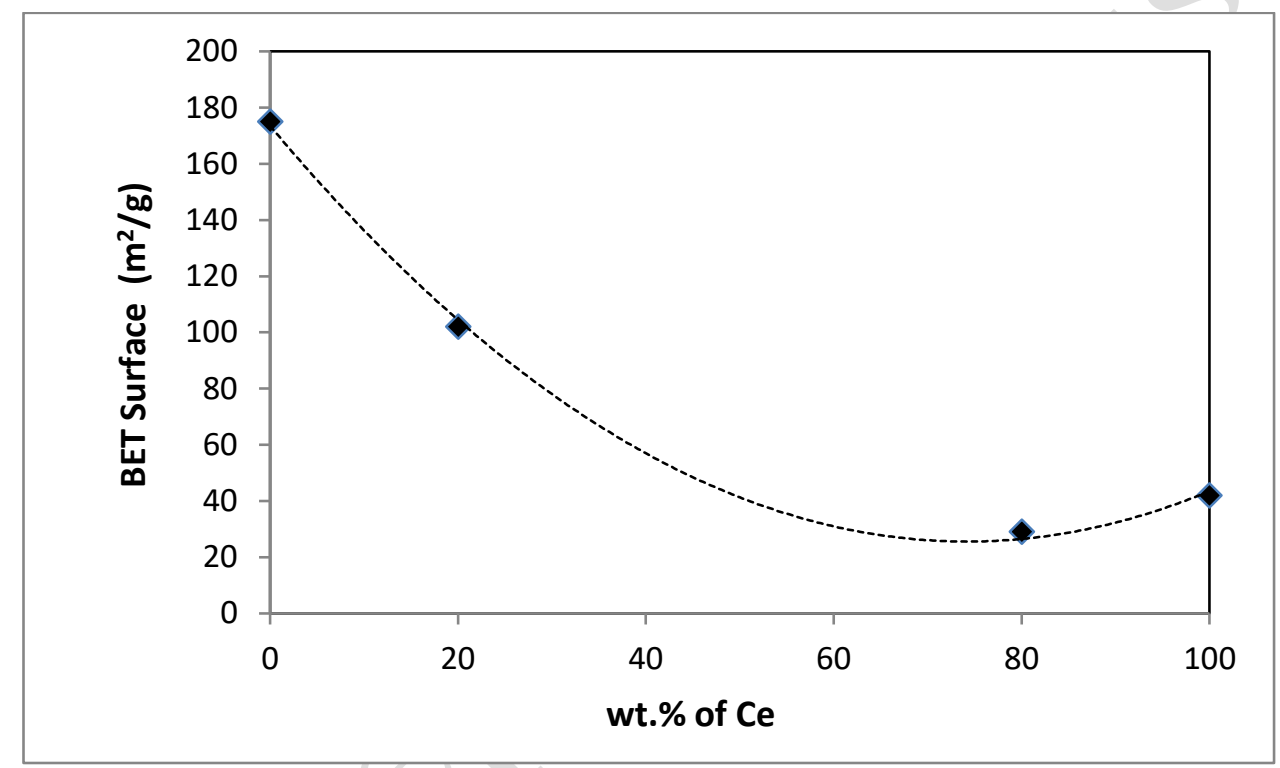

Figure 2 : Effect of the cerium content in $\mathrm{Rh} / \mathrm{Al}(\mathrm{Cex})$ catalysts on the BET surface. 


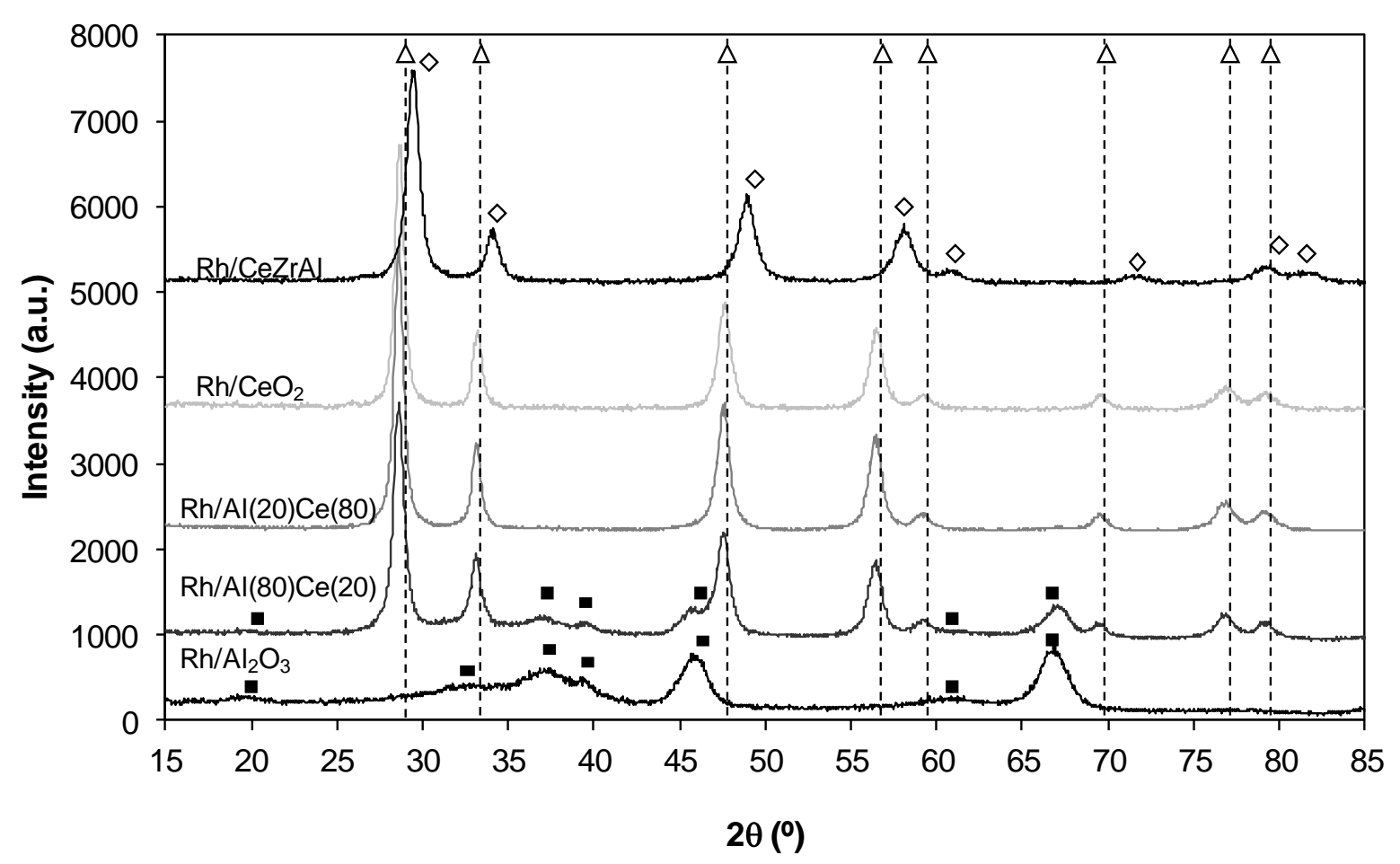

Figure 3 : X-Ray diffraction patterns of the $\mathrm{Rh} / \mathrm{Al}(\mathrm{Cex})$ series and of the $\mathrm{Rh} / \mathrm{CeZrAl}$ catalyst ; $(\mathbf{\square}): \gamma-\mathrm{Al}_{2} \mathrm{O}_{3} ;(\Delta): \mathrm{CeO}_{2} ;(\diamond): \mathrm{Ce}_{0.5} \mathrm{Zr}_{0.5} \mathrm{O}_{2}$.

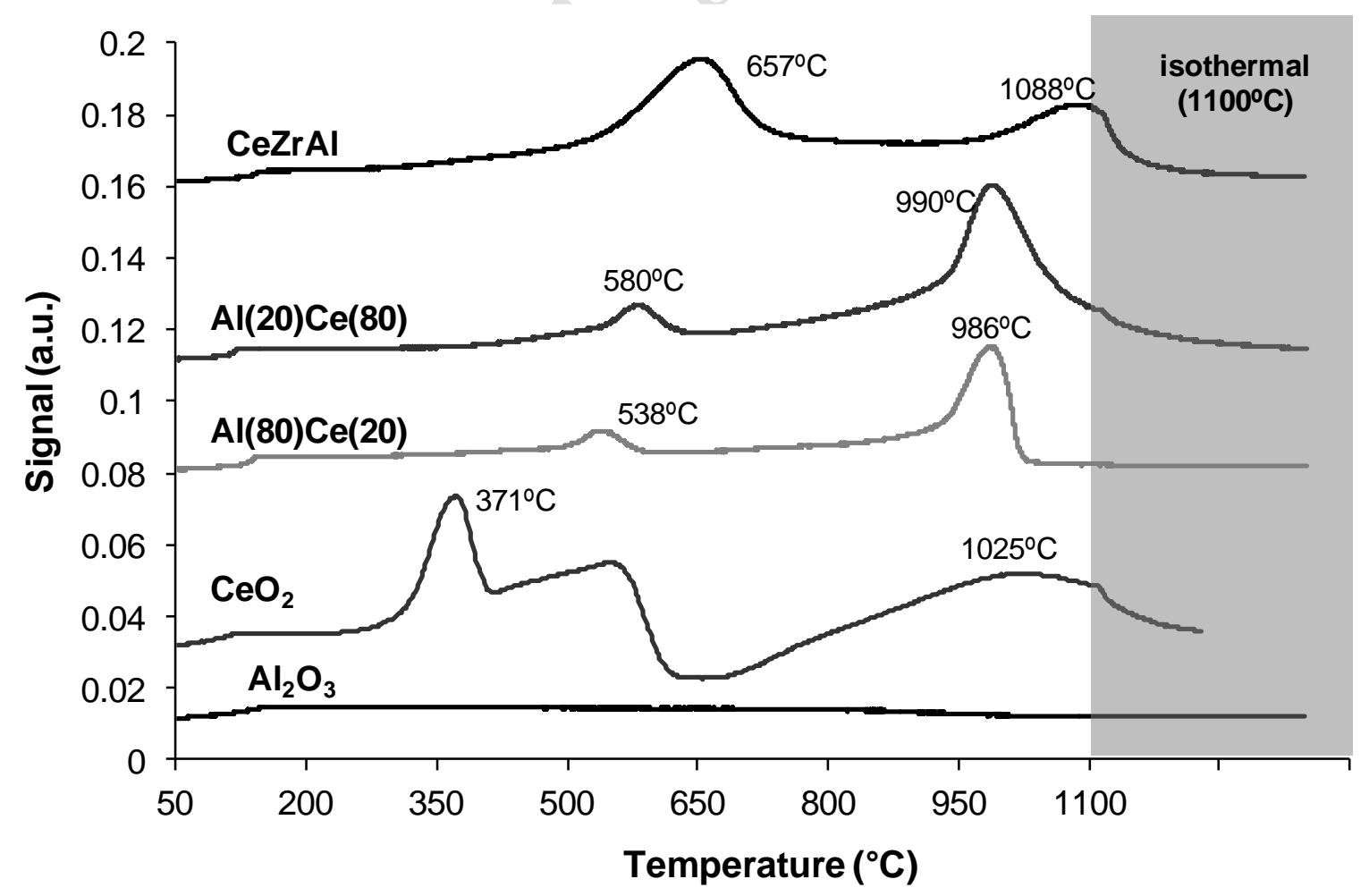

Figure 4: TPR profiles of the $\mathrm{Al}(\mathrm{Cex})$ series and $\mathrm{CeZrAl}$. 


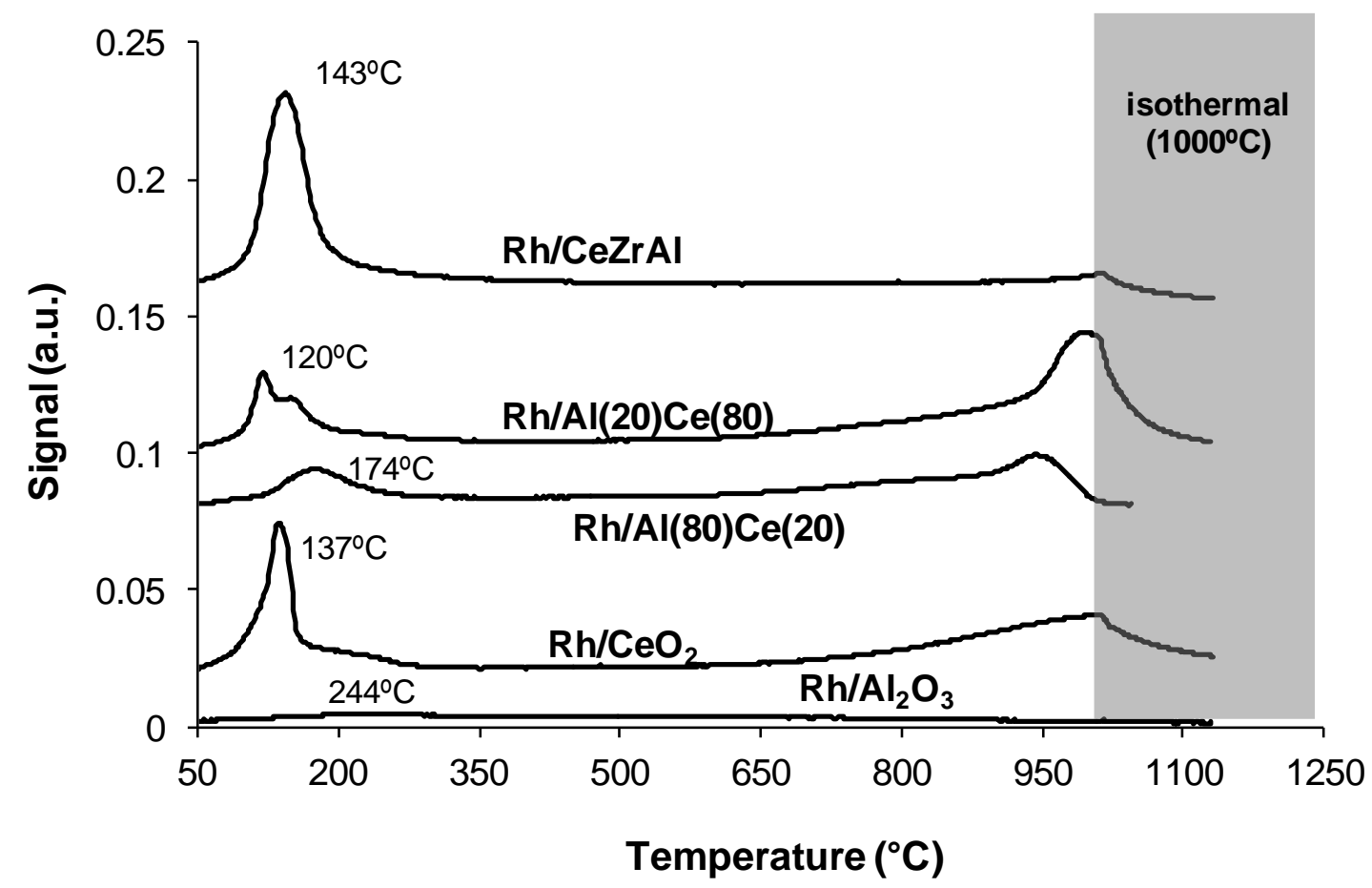

Figure 5: TPR profiles of $\mathrm{Rh} / \mathrm{Al}(\mathrm{Cex})$ series and $\mathrm{Rh} / \mathrm{CeZrAl}$. 

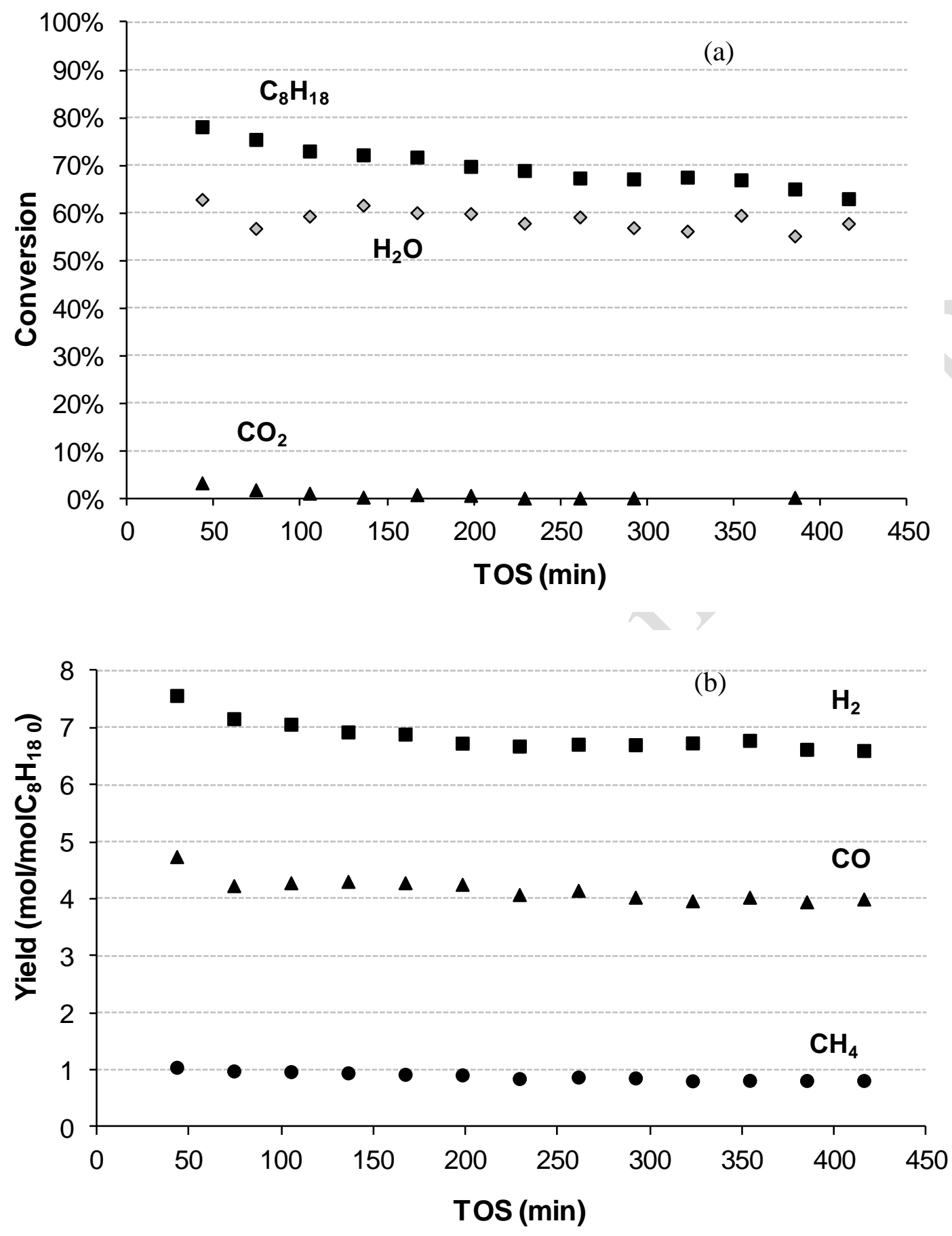

Figure 6 : Conversion of reactants (a) and products distribution (b) as a function of TOS for $\mathrm{Rh} / \mathrm{Al}_{2} \mathrm{O}_{3}$ catalyst at $580^{\circ} \mathrm{C}$ after activation under $\mathrm{H}_{2}$. 


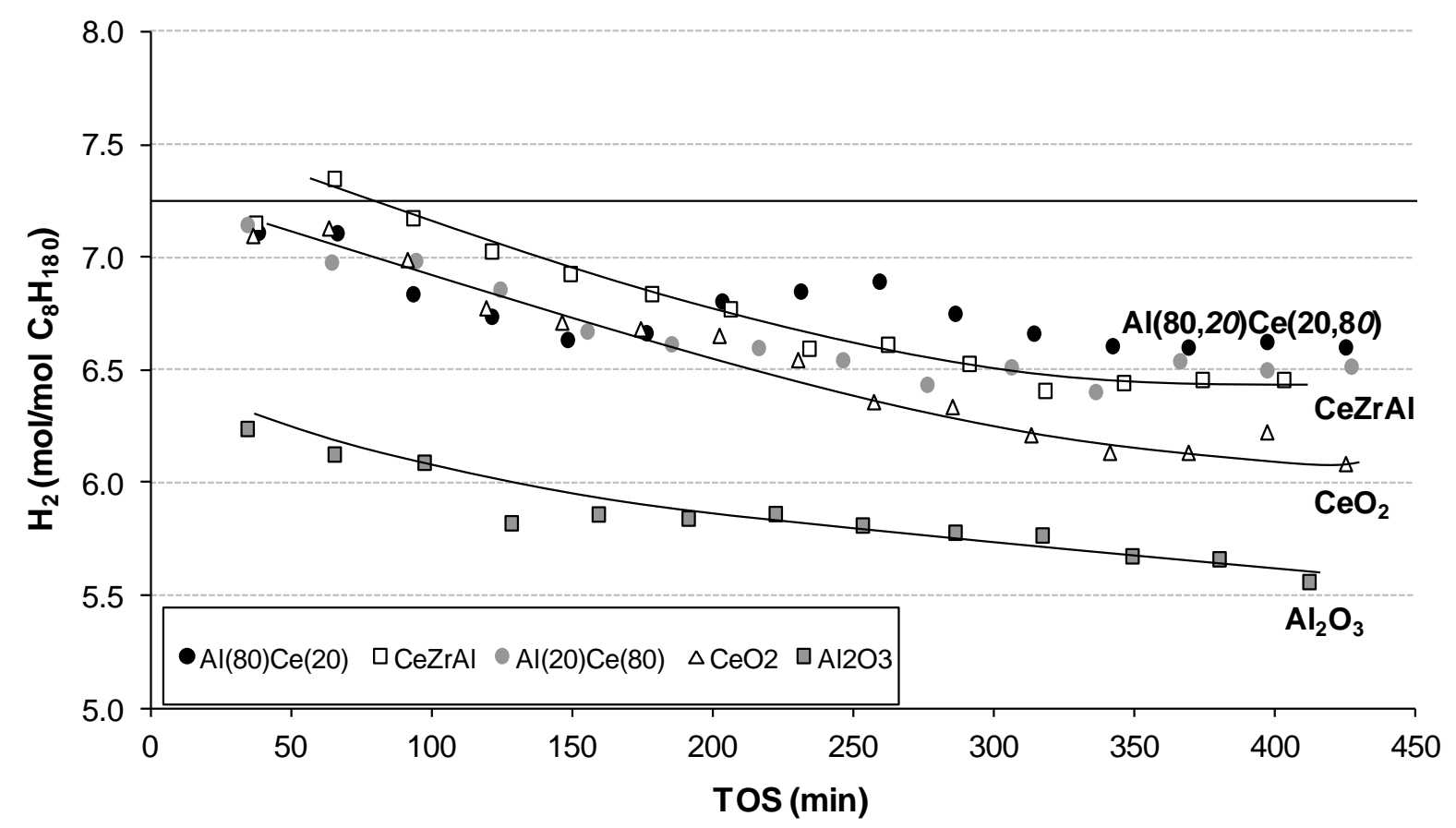

Figure 7 : Yield in $\mathrm{H}_{2}$ as a function of $\mathrm{TOS}$ for $\mathrm{Rh} / \mathrm{Al}(\mathrm{Cex})$ and $\mathrm{Rh} / \mathrm{CeZrAl}$ catalysts at $580^{\circ} \mathrm{C}$ after activation under reaction conditions. 

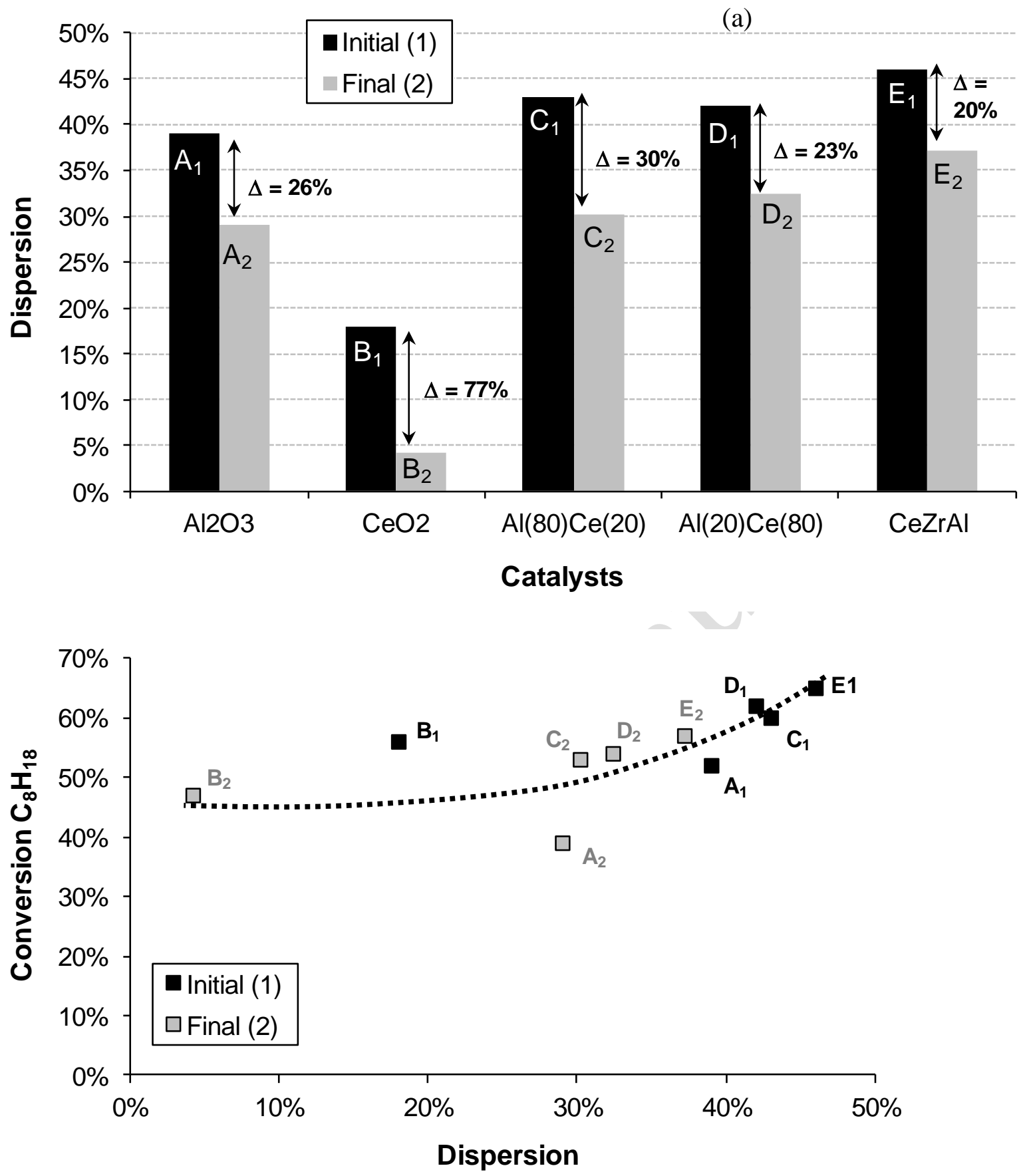

Figure 8: Comparison of the metal dispersion of the fresh (initial : A1, B1, C1, D1 and E1) and used (final : A2, B2, C2, D2 and E2) for $\mathrm{Rh} / \mathrm{Al}(\mathrm{Cex})$ and $\mathrm{Rh} / \mathrm{CeZrAl}$ catalysts (a) and evolution of the conversion of $\mathrm{C}_{8} \mathrm{H}_{18}$ as a function of initial and final metal dispersions. 